УдК 616.344-002-031.84-085.276-076-072.1

DOI 10.11603/2414-4533.2020.3.11457

\author{
СЯ. П. ФЕЛЕШТИНСЬКИЙ, О. О. ДЯДИК, А. О. МИЛЯНОВСЬКА, В. Ю. ПИРОГОВСЬКИЙ
}

Національна медична академія післядипломної освіти імені П. Л. Шупика, Київ

\title{
Відеокапсульна ендоскопія в діагностиці хвороби Крона
}

\begin{abstract}
Мета роботи: підвищити ефективність діагностики хвороби Крона.
Матеріали і методи. Проведено аналіз діагностики 288 пацієнтів із синдромом подразненої кишки. Залежно від діагностичної тактики пацієнти були розділені на 2 групи. Групи хворих були порівняними за віком та статтю. В першу групу увійшли пацієнти з синдромом подразненої кишки за період з 2010 по 2013 роки, яким виконувалася діагностика традиційними методами без застосування відеокапсульної ендоскопії. Дана група налічувала 143 пацієнти (49,6 \%). У другій групі пацієнтам проводилася діагностика за розробленим нами алгоритмом, тобто з застосуванням відеокапсульної ендоскопії, ілеоколоноскопії та за необхідністю ентероскопії із забором біопсії з уражених ділянок. Дана група налічувала 145 пацієнтів (50,3 \%).

Результати досліджень та їх обговорення. Отримані результати обстеження пацієнтів першої та другої групи показали, що хвороба Крона була виявлена у 20 (13,9 \%) пацієнтів першої групи та завдяки використанню відеокапсульної ендоскопії, колоноскопії, ентероскопії, біопсії була виявлена у 48 (33,1%) пацієнтів другої групи. Крім цього, у 68 пацієнтів першої групи 3 діагнозом синдром подразненої кишки, які знаходилися під динамічним спостереженням у нашій клініці, було проведено обстеження за розробленим алгоритмом. Результати показали, що у 25 (36,7 \%) пацієнтів з 68 було виявлено хворобу Крона тонкої кишки.
\end{abstract}

Ключові слова: хвороба Крона; відеокапсульна ендоскопія; ілеоколоноскопія; ентероскопія; біопсія.

Постановка проблеми і аналіз останніх досліджень та публікацій. Актуальність проблеми хвороби Крона на початку XXI століття визначається збільшенням частоти цього захворювання, труднощами діагностики та незадовільними результатами лікування. Діагностика хвороби Крона у більшості пацієнтів (60 \%) встановлюється на пізніх стадіях при розвитку ускладнень, що зумовлено варіабельністю як клінічних проявів, так і морфологічних змін у кишечнику, які труднодоступні діагностиці загальноприйнятими методами. Складність та несвоєчасність діагностики хвороби Крона часто призводять до розвитку ускладнень та інвалідизації [4, 6, 9].

Найчастіше хвороба Крона уражає клубову кишку. За даними літератури, ураження клубової кишки зустрічається у $40 \%$ пацієнтів із діагнозом хвороба Крона. Крім того, патологічні зміни в тонкій кишці при цьому захворюванні переважно супроводжуються незначно вираженою клінічною картиною та часто є причиною розвитку різних ускладнень (перитоніт, кишкові нориці, абсцеси, стриктури кишки). Необхідність у хірургічному лікуванні виникає у 90 \% пацієнтів протягом 10 років захворювання. У зв'язку з цим надзвичайно важливою $є$ рання діагностика даного захворювання, призначення відповідного лікування та зменшення частоти хірургічних ускладнень $[2,5,7,8]$.

Для діагностики хвороби Крона застосовують традиційні методи: гастроскопію, колоноскопію, комп’ютерну томографію, ультразвукову діагнос- тику. В той же час, ці методи не дозволяють вчасно встановити остаточний діагноз та відповідно визначити лікувальну тактику $[1,3]$. На наш погляд, використання сучасних методів діагностики, зокрема, таких як відеокапсульна ендоскопія та іліоколоноскопія з біопсією змінених ділянок кишечника, дасть можливість встановити діагноз хвороби Крона на ранній стадії.

Мета роботи: підвищити ефективність діагностики хвороби Крона.

Матеріали і методи. Проведений аналіз діагностики 288 пацієнтів з синдромом подразненої кишки віком від 17 до 65 років. Середній вік становив $(41 \pm 1,1)$ року. Серед них чоловіків було 142 (49,4 \%), жінок 146 (50,6 \%). Всі вони знаходилися на обстеженні та лікуванні у клініці кафедри хірургії і проктології НМАПО імені П. Л. Шупика на базі Київської обласної клінічної лікарні.

Залежно від діагностичної тактики пацієнти були розділені на 2 групи.

У першу групу увійшли 143 пацієнти з синдромом подразненої кишки, яким виконувалася діагностика традиційними методами за період з 2010 по 2013 роки. Традиційні методи діагностики включали вивчення скарг, анамнезу, об'єктивне обстеження, лабораторні обстеження, гастроскопію, колоноскопію, біопсію, гістологічне дослідження уражених ділянок кишки та ультразвукову діагностику.

У другу групу увійшли 145 пацієнтів з синдромом подразненої кишки, яким діагностика про- 
водилася 3 використанням розробленого алгоритму (патент на корисну модель № 140449 від 25.02.2020 р.) за період з 2014 по 2017 роки. Суть алгоритму полягала в тому, що крім традиційних методів діагностики, зокрема ультразвукового дослідження черевної порожнини, гастроскопії, виконувалася відеокапсульна ендоскопія та ілеоколоноскопія з біопсією з уражених ділянок кишки. У разі виявлення патологічних змін слизової оболонки тонкої кишки за допомогою відеокапсульної ендоскопії додатково виконувалася ентероскопія з біопсією. Відеокапсульна ендоскопія дозволяла визначити локалізацію ураження у тонкій кишці та чітко визначити напрям ентероскопії: антеградний чи ретроградний. Крім цього, відеокапсульна ендоскопія давала можливість визначити, на якій відстані від ілеоцекального кута знаходиться ураження клубової кишки, а це, у свою чергу, допомагало визначати необхідну глибину ілеоколоноскопії для проведення біопсії. Групи хворих були порівняними за віком та статтю.

Пацієнти обох груп готувалися до обстеження препаратами макроголів згідно з інструкцією та дотримувалися безшлакової дієти протягом двох днів перед обстеженням.

Розроблений нами алгоритм діагностики відрізняється від традиційних методів обстеження тим, що він дає можливість оглянути всі відділи шлунково-кишкового тракту, чітко локалізувати ділянки ураження та дає можливість взяття біопсії у тонкій кишці для гістологічної верифікації діагнозу.

Відеокапсульну ендоскопію було проведено 3 використанням системи OMOM 1, яка складається з трьох основних частин: інтелектуальної капсули (капсули), пристрою для запису зображення (пристрій запису) та комп’ютерної програми ОМОМ. Після проковтування капсула просувається по травному тракту, безперервно знімає слизову оболонку кишки та за допомогою сигналів у реальному часі передає зняті зображення на записуючий пристрій, де вони зберігаються. Далі за допомогою комп’ютерної програми ОМОМ проводиться аналіз отриманих результатів. Особливо важливим при виконанні відеокапсульної ендоскопії $є$ виявлення патологічних змін слизової кишечника, які можуть бути недосяжними при виконанні ілеоколоноскопії. Після виявлення змін у кишечнику, зокрема інфільтратів, ерозій, виразок та їх чіткої локалізації виконувалася ілеоколоноскопія та при необхідності ентероскопія з біопсією з уражених ділянок кишки. Ілеоколоноскопія та ентероскопія були проведені на ендоскопах фірми PENTAX EPK-i7000 та OLYMPUS EVIS EXEPA III CV - 190.
При патоморфологічному дослідженні отримані біоптати фіксували в 10 \% розчині нейтрального забуференного формаліну $(\mathrm{pH} 7,4)$ протягом не менш 24-36 годин, проводили за стандартною методикою та заливали в парафін. 3 парафінових блоків на ротаційному мікротомі НМ 325 (Thermo Shandon, Англія) виготовляли серійні гістологічні зрізи товщиною 4-5 мкм, які потім забарвлювали гематоксиліном та еозином, ставилась PASреакція. У випадках було проведено імуногістохімічне дослідження (ІГХД) $з$ використанням системи детекції з хромогеном UltraVision Quanto HRP DAB Quanto (Thermo Fisher Scientific, СШA). Нами було використано моноклональні антитіла (MAT) мишині до CD138 (клон MI 15), CD68 (клон KP1), CD20 (клон L26), $\alpha$-SMA (1A4(asm-1)) [10]. Мікроскопічне дослідження та фотоархівування проводили із використанням світлооптичного мікроскопа Zeiss (Німеччина) "Primo Star" (Німеччина) з системою обробки даних та камерою Axiocam105 color при збільшені об’єктивів $4 \times, 10 \times, 40 \times$, бінокулярної насадки 1,5 та окулярів WF $10 \times / 18$.

За отриманими результатами визначалася лікувальна тактика.

Результати досліджень та їх обговорення. Результати обстеження пацієнтів першої групи, яким проводилася діагностика традиційними методами, представлено в таблиці 1.

Таблиця 1. Результати обстеження пацієнтів I групи

\begin{tabular}{||l|c|c||}
\hline \multicolumn{1}{|c|}{ Діагноз } & Кількість пацієнтів & $\%$ \\
\hline СПК & 68 & 47,5 \\
\hline Хронічний коліт & 30 & 20,9 \\
\hline $\begin{array}{l}\text { Хронічний } \\
\text { гастродуоденіт }\end{array}$ & 25 & 17,4 \\
\hline Хвороба Крона & 20 & 13,9 \\
\hline Всього & 143 & 100 \\
\hline
\end{tabular}

За даними таблиці 1, згідно з результатами обстеження традиційними методами з урахуванням гістологічного висновку, було встановлено наступні діагнози: синдром подразненої кишки у 68 (47,5 \%) пацієнтів, хронічний коліт у 30 (20,9 \%), хронічний гастродуоденіт у 25 (17,4 \%) та хвороба Крона у 20 (13,9 \%). Синдром подразненої кишки було встановлено у 68 пацієнтів, які не мали органічної патології з боку слизової оболонки верх- 
ніх відділів травного тракту та товстої кишки, але мали клінічні прояви. Хвороба Крона була встановлена лише у 20 пацієнтів, цим пацієнтам було призначено відповідне лікування. Хвороба Крона була підтверджена комплексним патоморфологічних дослідженням, в частині випадків спостерігалось гранулематозне запалення.

Результати обстеження пацієнтів у другій групі за розробленим алгоритмом представлено в таблиці 2.

\section{II групи}

Таблиця 2. Результати обстеження пацієнтів

\begin{tabular}{||l|c|c||}
\hline \multicolumn{1}{||}{ Діагноз } & Кількість пацієнтів & $\%$ \\
\hline $\begin{array}{l}\text { Хронічний } \\
\text { гастродуоденіт }\end{array}$ & 52 & 35,8 \\
\hline Хвороба Крона & 48 & 33,1 \\
\hline СПК & 23 & 15,8 \\
\hline Хронічний коліт & 22 & 15,1 \\
\hline Всього & 145 & 100 \\
\hline
\end{tabular}

У пацієнтів другої групи за результатам відеокапсульної ендоскопії з урахуванням гістологічного висновку встановлено хронічний гастродуоденіт у 52 (35,8 \%) пацієнтів, хворобу Крона у 48 (33,1 \%), (рис. 1), синдром подразненої кишки у 23 $(15,8 \%)$ та хронічний коліт у $22(15,1 \%)$.

У 8 (5,5 \%) пацієнтів другої групи, за результатами відеокапсульної ендоскопії, виявлено ураження у середній третині голодної кишки, цим пацієнтам проведено антеградну ентероскопію з біопсією уражених ділянок.

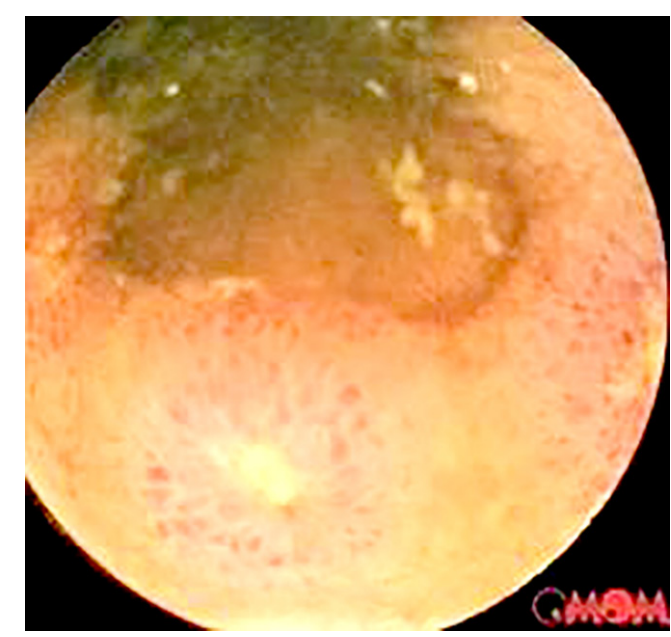

Рис. 1. Виразки клубової кишки.
При патоморфологічному дослідженні в тонкому кишечнику спостерігалась переважно збережена архітектоніка, нерівність поверхневих відділів, невеликі ділянки ерозування, вогнищево поліморфно-ядерні лейкоцити на поверхні, в окремих випадках ділянки за типом щілиноподібних виразок, вогнищево ентеролізація залоз, в ділянках виразкування та навколо них в окремих залозах в просторі - фібрин, злущені клітини, лімфоцити, моноцити, поодинокі нейтрофільні лейкоцити (рис. 2), переважно виражена лімфо-гістіоцитарна з домішкою еозинофільних лейкоцитів та плазматичних клітин інфільтрація, яка розповсюджуєть-

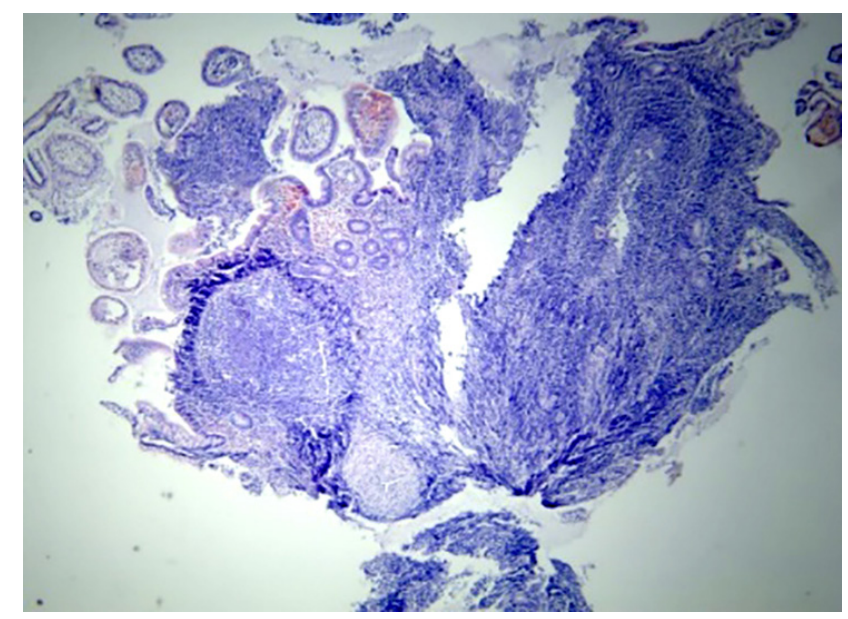

Рис. 2. Хвороба Крона, тонка кишка, щілиноподібна виразка, гранулемоподібний характер клітинного інфільтрату, гранулема в зоні власної пластинки. Забарвлення гематоксиліном та еозином, збільшення $\times 40$.

ся від власної пластинки до поверхневих відділів слизової оболонки, на окремих ділянках клітинні інфільтрати мають обмежений характер, у частині випадків зустрічались епітеліоїдно-клітинні гранулеми (рис. 2, 3), ділянки розростання грануляційної та сполучної тканини в зонах клітинної інфільтрації, в зоні власної пластинки ознаки васкуліту та склероз частини судин; PAS-реакція - секреція слизу переважно збережена в залозах, частині клітин знижена, в окремих залозах зменшена кількість келихоподібних клітин (рис. 4).

При ІГХД спостерігалось збереження перикріптальних міофібробластів із вираженою позитивною експресією $\alpha$-SMA (рис. 5), виражений базальний плазмоцитоз (рис. 6), наявність макрофагів та В-ліміфоцитів у ділянках клітинних інфільтратів.

За результатами відеокапсульної ендоскопії у 22 (15,1 \%) пацієнтів ураження локалізувалося у

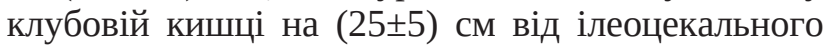




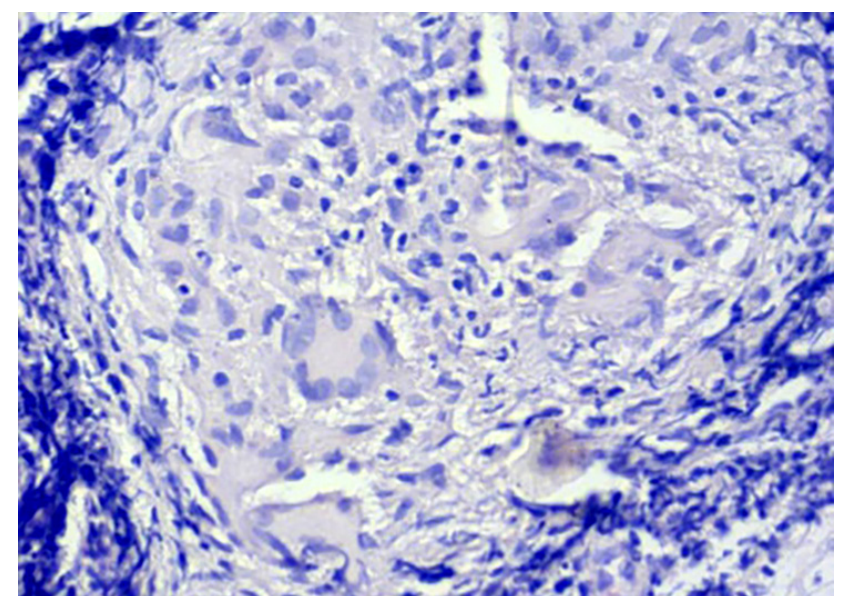

Рис. 3. Хвороба Крона. Тонка кишка, в зоні власної пластинки епітеліоїдно-клітинна гранулема. Забарвлення гематоксиліном та еозином, збільшення $\times 400$.

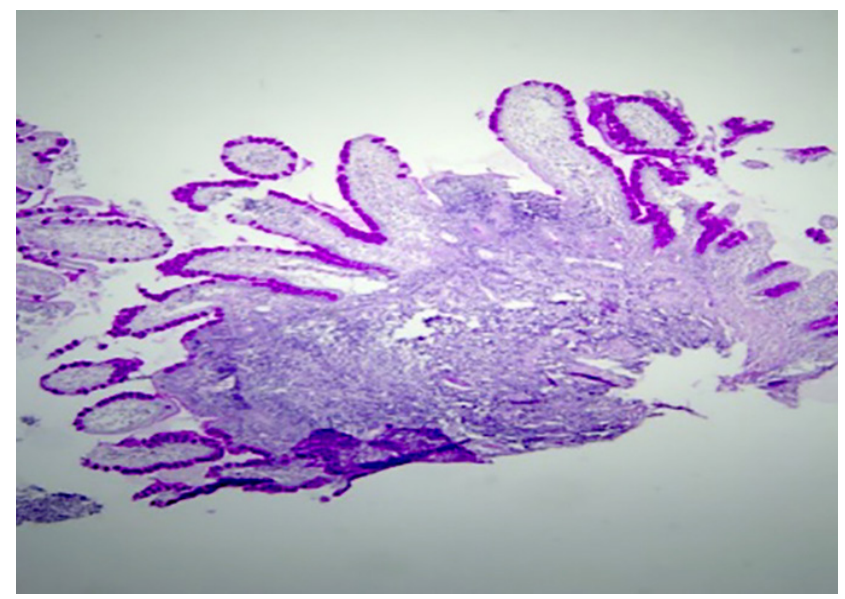

Рис 4. Хвороба Крона. Тонка кишка, збереження секреції слизу, вогнищеве зменшення кількості келихоподібних клітин. PAS-реакція, збільшення $\times 40$.

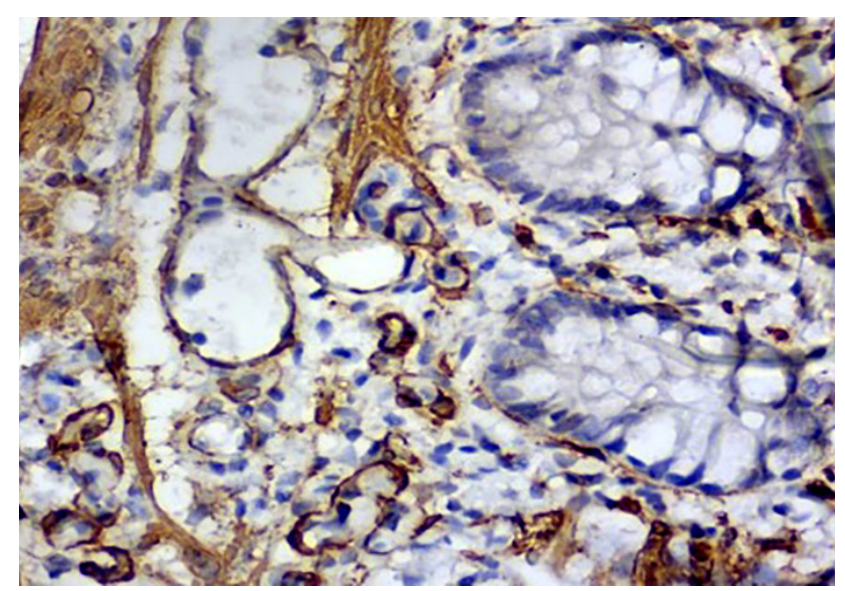

Рис. 5. Хвороба Крона. Тонка кишка, виражена експресія перикріптальних міофібробластів/фібробластів, позитивна експресія фібробластів в зоні клітинних інфільтратів. ІГХД з МАТ до $\alpha-\mathrm{SMA}$, збільшення $\times 400$.

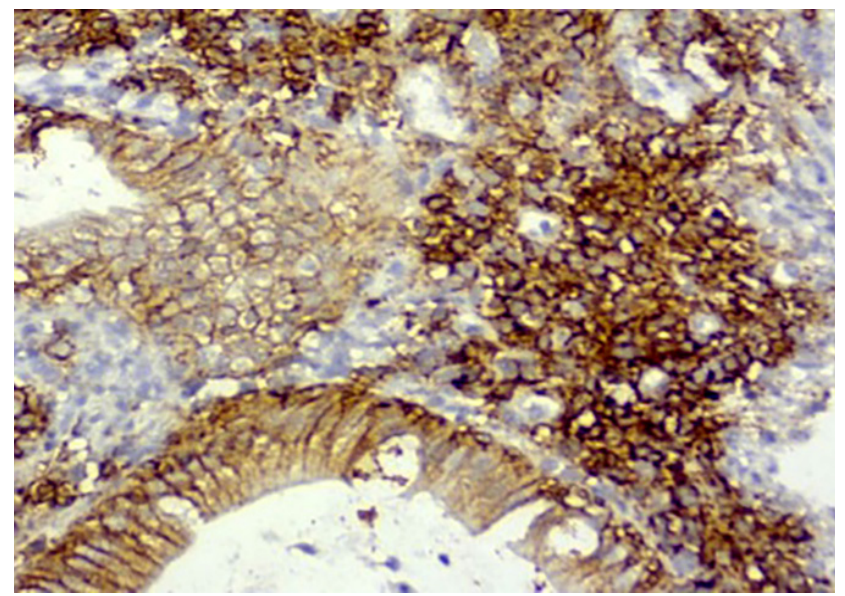

Рис. 6. Хвороба Крона. Тонка кишка, позитивна експресія плазматичних клітин у базальних відділах слизової оболонки. ІГХД з МАТ до CD138, збільшення ×400.

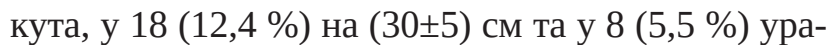
ження локалізувалося у голодній кишці.

Отримані результати обстеження пацієнтів 3 синдромом подразненої кишки показали, що серед пацієнтів першої групи хвороба Крона була виявлена у 20 (13,9 \%), тоді як серед пацієнтів другої групи - у 48 (33,1%). Виявлення більшої кількості хворих з хворобою Крона серед пацієнтів другої групи порівняно з першою групою досягнуто за рахунок використання розробленого алгоритму зокрема з використанням відеокапсульної енодоскопії, ілеоколоноскопії, ентероскопії та морфологічного дослідження слизової кишечника. Підтвердження ефективності використання розробленого алгоритму діагностики хвороби Крона було доведено також серед 68 пацієнтів з першої групи 3 синдромом подразненої кишки, які знаходилися під динамічним спостереженням у клініці. Серед них у 25 (36,7 \%) було виявлено хворобу Крона тонкої кишки, у 40 (58,8 \%) лімфоїдну гіперплазію клубової кишки, в 1 (1,4 \%) целіакію та у 2 (2,9 \%) не виявлено патологічних змін. Зокрема завдяки відеокапсульній ендоскопії патологічні зміни тонкої кишки були виявлені на 30 см від ілеоцекального кута. Виконання ілеоколоноскопії, ентероскопії, біопсії з комплексним патоморфологічним дослідженням підтвердили діагноз. Ці результати також підтвердили більш високу діагностичну ефективність розробленого алгоритму порівняно з традиційними методами.

Всім пацієнтам 3 діагностованою хворобою Крона призначено курс базисної терпії. Базисна терапія включала: дієта № 4, Пентаса 5.0 гр. на добу, Креон 1 таб. х 3 р/д, нейровітан по 1 таб. 3 р/д, фолієва кислота по 1 таб. 3 р/д. 
Таким чином, ефективність діагностики хвороби Крона при синдромі подразненої кишки значно підвищується шляхом використання розробленого алгоритму з відеокапсульною ендоскопією, ілеоколоноскопією та біопсією, що дозволяє на ранніх стадіях захворювання встановити правильний діагноз призначити лікування.

\section{СПИСОК ЛІТЕРАТУРИ}

1. Brant S. R. Promises, delivery, and challenges of inflammatory bowel disease risk gene discovery / S. R. Brant // Clin. Gastroenterol. Hepatol. - 2013. - Vol. 11. - P. 22-26. DOI: https:// doi. org/10.1016/j.cgh.2012.11.001.

2. Epidemiology and natural history of inflammatory bowel diseases / J. Cosnes, C. Gower-Rousseau, P. Seksik, A. Cortot // Gastroenterology. - 2011. - Vol. 140 (6). - P. 1785-1794. DOI: https://doi.org/10.1053/j.gastro.2011.01.055.

3. Increasing incidence and prevalence of the inflammatory bowel diseases with time, based on systematic review / N. A. Molodecky, I. S. Soon, D. M. Rabi [et al.] // Gastroenterology. 2012. - Vol. 142. - P. 46. DOI: https://doi.org/10.1053/j.gastro.2011.10.001.

4. European evidence based consensus for endoscopy in inflammatory bowel disease / V. Annese, M. Daperno, M. D. Rutter [et al.] // J. Crohns Colitis. - 2013. - Vol. 7 (12). - P. 982-1018. DOI: https://doi.org/10.1016/j.crohns.2013.09.016.

5. The Manitoba Inflammatory Bowel Disease Cohort Study: Prolonged symptoms before diagnosis - how much is irritable bowel syndrome? / T. Burgmann, I. Clara, L. Graff [et al.] // Clin. Gastroenterol. Hepatol. - 2006. - Vol. 4. - P. 614. DOI: https:// doi.org/10.1016/j.cgh.2006.03.003.

\section{REFERENCES}

1. Brant, S.R. (2013). Promises, delivery, and challenges of inflammatory bowel disease risk gene discovery. Clin. Gastroenterol. Hepatol., 11, 22-26. DOI: https://doi.org/10.1016/j.cgh.2012.11.001 2. Cosnes, J., Gower-Rousseau, C., Seksik, P., \& Cortot, A. (2011). Epidemiology and natural history of inflammatory bowel diseases. Gastroenterology, 140 (6), 1785-1794. DOI: https:// doi. org/10.1053/j.gastro.2011.01.055.

3. Molodecky, N.A., Soon, I.S., Rabi, D.M., Ghali, W.A., Ferris, M., Chernoff, G., et al. (2012). Increasing incidence and prevalence of the inflammatory bowel diseases with time, based on systematic review. Gastroenterology, 142, 46. DOI: https://doi. org/10.1053/j.gastro.2011.10.001.

4. Annese, V., Daperno, M., Rutter, M.D., Amiot, A., Bossuyt, P., East, J., et al. (2013). European evidence based consensus for endoscopy in inflammatory bowel disease. J. Crohns Colitis, 7 (12), 982-1018. DOI: https://doi.org/10.1016/j.crohns.2013.09.016.

5. Burgmann, T., Clara, I., \& Graff, L. (2006). The Manitoba Inflammatory Bowel Disease Cohort Study: Prolonged symptoms before diagnosis - how much is irritable bowel syndrome? Clin. Gastroenterol. Hepatol., 4, 614. DOI: https://doi.org/10.1016/j. cgh.2006.03.003.
Висновок. Використання розробленого алгоритму діагностики з використанням відеокапсульної ендоскопії з ілеоколоноскопією та біопсією 3 комплексним патоморфологічних дослідженням при синдромі подразненої кишки дозволило на ранніх стадіях виявити хворобу Крона у 33,1 \% пацієнтів, тоді як традиційні методи дозволяють виявити хворобу Крона лише у $15 \%$.

6. Prospective comparison of computed tomography enterography and magnetic resonance enterography for assessment of disease activity and complications in ileocolonic Crohn's disease / G. Fiorino, C. Bonifacio, L. Peyrin-Biroulet [et al.] // Inflamm. Bowel Dis. - 2011. - Vol. 17 (5). -P. 1073-1080. DOI: https:// doi.org/10.1002/ibd.21533.

7. Green C. A population-based ecologic study of inflammatory bowel disease: searching for etiologic clues / C. Green // Am. J. Epidemiol. - 2006. - P. 164; 615; discussion 624. DOI: https:// doi.org/10.1093/aje/kwj260.

8. Akerman P. A. Spiral enteroscopy and push enteroscopy / P. A. Akerman, D. Cantero // Gastrointest. Endosc. Clin. N. Am. 2009. - Vol. 19 (3). -P. 357-369. DOI: https://doi.org/10.1016/j. giec.2009.04.001.

9. Role of small-bowel endoscopy in the management of patients with inflammatory bowel disease: an international OMED-ECCO consensus / A. Bourreille, A. Ignjatovic, L. Aabakken [et al.] // Endoscopy. - 2009. -Vol. 41 (7). - P. 618-637. DOI: https://doi. org/10.1055/s-0029-1214790.

10. Vinay Kumar. Robbins and Cotran pathologic basis of disease. Ninth Edition / Vinay Kumar, Abul K. Abbas, Jon C. Aster. - 2015. - P. 445-479.

6. Fiorino, G., Bonifacio, C., Peyrin-Biroulet, L., Minuti, F., Repici, A., Spinelli, A., et al. (2011). Prospective comparison of computed tomography enterography and magnetic resonance enterography for assessment of disease activity and complications in ileocolonic Crohn's disease. Inflamm. Bowel Dis. 17 (5), 10731080. DOI: https://doi.org/10.1002/ibd.21533.

7. Green, C. (2006). A population-based ecologic study of inflammatory bowel disease: searching for etiologic clues. Am. J. Epidemiol., 164; 615; discussion 624. DOI: https://doi. org/10.1093/aje/kwj260.

8. Akerman, P.A., \& Cantero, D. (2009). Spiral enteroscopy and push enteroscopy. Gastrointest. Endosc. Clin. N. Am., 19 (3), 357369. DOI: https://doi.org/10.1016/j.giec.2009.04.001.

9. Bourreille, A., Ignjatovic, A., Aabakken, L., Loftus, Jr. E.V., Eliakim, R., Pennazio, M., et al. (2009). Role of small-bowel endoscopy in the management of patients with inflammatory bowel disease: an international OMED-ECCO consensus. Endoscopy, 41 (7), 618-637. DOI: https://doi.org/10.1055/s-0029-1214790. 10. Vinay Kumar, Abul K. Abbas, Jon C. Aster (2015). Robbins and Cotran Pathologic Basis of Disease. Ninth Edition.

Отримано 05.05.2020 
YA. P. FELESTINSKY, O. O. DYADYK, A. O. MILYANOVSKAYA, V. YU. PIROGOVSKY

P. Shupk National Medical Academy of Postgraduate Education, Kyiv

\section{VIDEO CAPSULE ENDOSCOPY IN THE DIAGNOSIS OF CROHN'S DISEASE}

The aim of the work: to improve the effectiveness of diagnosis of Crohn's disease.

Materials and Methods. The study analyzed 288 patients with irritable bowel syndrome. Depending on the diagnostic tactics, patients were divided into 2 groups. Groups of patients were comparable in age and sex.

Group 1 included patients with irritable bowel syndrome for the period from 2010 to 2013, who were diagnosed by traditional methods without the use of video capsule endoscopy. This group consisted of 143 patients (49.6\%). Group 2 of patients were diagnosed according to the algorithm developed by us, using video capsule endoscopy, ileocolonoscopy and, if necessary, enteroscopy with biopsy from the affected areas. This group consisted of 145 patients (50.3\%).

Results and Discussion. The results of the examination of patients of the first and second groups showed that Crohn's disease was detected in 20 (13.9\%) patients of the group 1 and due to the use of video capsule endoscopy, colonoscopy, enteroscopy, biopsy was detected in 48 (33.1\%) patients of the group 2. In addition, 68 patients of the group 1 with a diagnosis of irritable bowel syndrome, who were under dynamic observation in our clinic, were examined according to the developed algorithm. The results showed that 25 (36.7 \%) patients out of 68 had Crohn's disease of the small intestine.

Key words: Crohn’s disease; video capsule endoscopy; ileocolonoscopy; enteroscopy; biopsy.

\section{Я. П. ФЕЛЕШТИНСКИЙ, О. О. ДЯДИК, А. О. МИЛЯНОВСЬКАЯ, В. Ю. ПИРОГОВСКИЙ}

Национальная медицинская академия последипломного образования имени П. Л. Шупика, Киев

\section{ВИДЕОКАПСУЛЬНАЯ ЭНДОСКОПИЯ ДЛЯ ДИАГНОСТИКИ БОЛЕЗНИ КРОНА}

Цель работы: повысить эффективность диагностики болезни Крона.

Материалы и методы. Проведен анализ диагностики 288 пациентов с синдромом раздраженной кишки. В зависимости от диагностической тактики пациенты были разделены на 2 группы. Группы больных были сопоставимы по возрасту и полу.

В первую группу вошли пациенты с синдромом раздраженной кишки за период с 2010 по 2013 года, которым выполнялась диагностика традиционными методами без применения видеокапсульной эндоскопии. Данная группа насчитывала 143 пациента (49,6 \%). Во второй группе пациентам проводилась диагностика по разработанному нами алгоритму, то есть с применением видеокапсульной эндоскопии, илиоколоноскопии и при необходимости энтероскопии с забором биопсии с пораженных участков. Данная группа насчитывала 145 пациентов (50,3 \%).

Результаты исследований и их обсуждение. Полученные результаты обследования пациентов первой и второй группы показали, что болезнь Крона была обнаружена у 20 (13,9\%) пациентов первой группы и благодаря использованию видеокапсульной эндоскопии, колоноскопии, энтероскопии, биопсии была обнаружена у 48 (33,1 \%) пациентов второй группы. Кроме этого, в 68 пациентов первой группы с диагнозом синдром раздраженной кишки, которые находились под динамическим наблюдением в нашей клинике, было проведено обследование по разработанному алгоритму. Результаты показали, что у 25 (36,7 \%) пациентов из 68 была обнаружена болезнь Крона тонкой кишки.

Ключевые слова: болезнь Крона; видеокапсульна эндоскопия; илеоколоноскопия; энтероскопия; биопсия. 